\title{
Ferial Mirage (Fata Morgana)
}

\section{TRISH SALAH}

\begin{abstract}
he awoke to an appetite for narrative. Wanted to know who was a memory machine. Who was a memory. She was in a bed and she was entwined and twinned with, and she was nearly thought (the moon) she was nearing the moon. Two in a bed and the Witch, was it? Under the moon, heavy breasted, and plunged into it. It was only scary. What recursive thought isn't? She awoke to the moon, full and flaccid, stinking of drunken sex, sweet with it, like a child.
\end{abstract}

The romance is always two in bed and in another room, another. Some fey thing you thought you cast off, full. Under the moon, your familiar, you're twinned with her, cursive and strung out. Halfway across the city, or, its architecture. Your restlessness at six a.m., an appetite for water or memory, the sweat of it. You have the feeling of a wolf. Feral idylls, ferrous. The taste of lightning in your mouth. A moony child, switched in the night.

Two in a bed and through the window a gray line where dawn will come. It allows silhouette: trees, clouds, horizon. Her eyes on her lover rapt, knotted in Celtic shadow: silhouette. Who she was wakened to, her appetite? The feeling of a wolf or a child behind the door you locked. Or, eagles wrapped around my neck, at the collarbone, martial. Love with its histories of war and open to the band of light, a little hopeful music, at the horizon, the willingness of light, its capacity to diffuse, to allow others, palest blue, a yellow awning of dawn.

A witch, sucking her tit, beautiful as her familiar, and the precise articulation, the immediacy of tree branch silhouetted, black veins with an upward reach. (Old bones sucked, at the root.) Love against 
the dawn, sienna dissolving slate. Here with the bones of trees we're still in night, but the mist's uneven line speaks of how day may come through trees; they're horizon. It's a winter night anxious for day. Two in a bed are debating with dreams, which to allow. Which to wake to? Children under foot, whitening. Resentful? Too long with a pillow over her head.

Smothering is something you can't argue with bones. The past is the past and children should not die under foot, in the pretty jaws of a witch. Outside the sky is plunging trees. Clouds enjoy her sleeping smile. She is mindful of snow on the tracks, widening distance, a capacity for depth. With colors coming as inevitably as old lovers do, or not, when you are in danger, or asleep. Out another window, the city sky line feeling its own: blue thinning of darkness. Split root, your old man love is walking the rounds. The chill air is working its way every where like smoke into sky. Where diffused, every dawning is refused. A fey turn to the south. Like memory, like children. Its matter made from radiance, and your concern for freedom.

Where her freedom was concerned, the witch had her aversion to trains, trials, of thought that might ask of her uncertain lightness. She got out of bed, distracted with her moon and an appetite for water. Memory flood the dawn with others. Dawns she had cast off, not unkindly, but with an instinct for survival, and now? It was all comparative and her love enjoyed her sleeping smile. Her teeth hurt.

The city was lightening in the west and still she felt refusal from the moon. Full, and indifferent, the cut on her thumb from dinner the night before. Acid with having you, and unable to sleep. She was pulled a cloud's distance. (Once, there were others: old man law, that bad dad, and even courtly romance). She was aware of the necessity of certain fictions, more certainly of their failing. Often, she flattered herself, she was above all that. There were gulls in the widening distance and as a lover, as someone with some measure of dignity, of freedom. What galls at early dawn, pulling, as she wakes to snow, a little hung over, and dishes to be washed. Never the less she prized her freedom. Like a thief in the night. Love demands that, and one needs to be able to work, and then, or until, the backward glance. A certain distance (a collect call from Messina, or Tennessee). 
Fiction will do that for you. More, if you are a beautiful girl, as she was, and determined to be.

I swept over you before I came downstairs, and said sorry, not for leaving but for the before. My restlessness in bed and your sleep interrupted by the moon, which was being insistent with me. A fey child, locked outside and scratching, leaving a certain sickness in my mouth. One tries to be fair.

Last night, putting on my beautiful girl face, and playing with my hair, you are sweet to me. I need some water. I meant to say: she woke with a blood on the narrative, a fairy bias. Or was it mechanic? The taste of it, ferrous in her mouth, and the feeding of the dawn on night, nearby. How do you sleep through that? Luminous and plundering sleep, whole breaks of color, ask the impassibility of light. Where gold comes through palest, crimson tendrils, mauve surrounds, and palest, gold comes through. The sky and last night's party, all those politicians, all that red wine. It was only the nightmare of the last time that kept us in fiction. A certain distance. Overcome. We play it. For one moment, one of us, anyhow. The sun came up. Time to wash.

She awoke to an amber flush, gaudily more so. A less offensive word for Marrano, as if that could take the sting out. Deeper ocher, deeper maroon. The winds were at her and what they carried. Eagles' silhouette intruding with a sharpened edge, and her perception pierced with it. 